\title{
Household linkages in dispersed settlement around Pietersburg and implications for household resources management
}

\author{
SE Donaldson \& Elizabeth Boshoff
}

\section{OPSOMMING}

Hierdie artikel fokus op die skakelings tussen huishoudings in drie vorige tuislanddorpe in die omgewing van Pietersburg en Pietersburg as sentrale gebied. Die ondersoek is vanuit ' $n$ stedelik-geografiese oogpunt gedoen. Inligting oor die skakelings is in die lig van ' $n$ huishoudelike hulpmiddelbestuursraamwerk vertolk om die gevolge daarvan vir hulpmiddelbestuur in die huishoudings in die drie dorpe te ontleed.

Volgens die huishoudelike hulpmiddelbestuursraamwerk is huishoudings in interaksie met hul mikroömgewings asook met die wyer omgewing. Hierdie interaksie van die huishoudings met hul fisiese en sosiale mikroömgewings is kortliks ondersoek deur die huishoudings se voorkeur vir die dorpe waar hulle woon te ondersoek. Interaksies tussen die huishoudings en die politieke en ekonomiese subsisteme in die samelewing is ook ondersoek deur die skakelings wat die huishoudings met Pietersburg en die drie vorige tuislanddorpe het, die plek waar hulle werk, waar hulle inkopies doen en van finansiële dienste gebruik maak, waar die kinders skoolgaan en waar hulle aan ontspanningsaktiwiteite deelneem, te bestudeer.

Die vertolking van die stedelik-geografiese inligting en die implikasies daarvan vir hulpmiddelbestuur in hierdie huishoudings het daarop gedui dat samewerking tussen stedelike geograwe en verbruikerswetenskaplikes vrugbaar kan wees mits aan sekere detail aandag geskenk word wanneer die navorsing beplan word. Meer besonderhede oor die implikasies van die skakeling tussen huishoudings en hul omgewings kan vanuit die stanspoor ingewin word sodat die gevolge van die skakeling ten opsigte van die huishoudings se hulpmiddelbestuur dieper insigte tot gevolg kan hê.

\section{- Dr SE Donaldson}

Department of Geographical Sciences, Vista University

\section{- Prof Elizabeth Boshoff}

Department of Consumer Science, University of Pretoria

\section{INTRODUCTION}

Urban surveys by geographers contain useful information for consumer scientists in the field of household resources management. However, most urban linkage studies are conducted without using a framework that would make the information applicable and useful for household resources management purposes.

This article attempts to interpret the results of an urban linkage study in terms of household resources management to highlight their usefulness in this field. Gaps in the information derived from urban linkage studies could be prevented if these studies were planned and conducted in cooperation with consumer scientists in the field of household resources management. Such cooperation would enrich the research and be a step closer to the ideal of multidisciplinary approaches to finding solutions to current social problems.

During the previous political dispensation, four towns for black people were proclaimed in the present Northern Province, all within a radius of $60 \mathrm{~km}$ from Pietersburg which is the capital of the Province. The effect of these proclamations was to separate the black from the white population groups and to separate black tribal groups of the Sotho ethnic group from one another. The four towns are Mankweng (30 km from Pietersburg) which developed as an educational centre around the University of the North, Lebowakgomo (55 km from Pietersburg) which was the administrative centre for the previous Lebowa homeland, Seshego (13 km from Pietersburg) which was planned as an industrial growth point bordering Pietersburg, and Sebayeng which served as a dormitory town for workers in Seshego and Pietersburg.

The anticipated urban growth and development failed to materialise in Mankweng, Lebowakgomo and Seshego. Sebayeng was planned as a dormitory town and was therefore not expected to develop into a fullscale town. Because Sebayeng remained rural in character, with no economic development such as shops, banks or industries, it was not included in this urban linkages study.

Very few employment opportunities - apart from the public and education sectors - are available in the first-mentioned three towns. Table 1 presents a summary of the number of businesses in Lebowakgomo 
TABLE 1: NUMBER OF LISTED BUSINESSES IN SESHEGO AND LEBOWAKGOMO, 1997

\begin{tabular}{|l|c|c|}
\hline \multicolumn{1}{|c|}{ Employment sector } & Lebowakgomo & Seshego \\
\hline \multicolumn{1}{|c|}{ Primary and secondary sector } & & $3(2 \%)$ \\
\hline Agriculture & $5(4 \%)$ & $37(26 \%)$ \\
\hline Mining/industry/manufacturing & $12(9 \%)$ & $4(3 \%)$ \\
\hline Building & $13(10 \%)$ & $51(36 \%)$ \\
\hline \multicolumn{1}{|c|}{ Tertiary and quaternary sector } & & $24(17 \%)$ \\
\hline Shops & $57(44 \%)$ & $2(1 \%)$ \\
\hline Social/community services & $18(14 \%)$ & $142(100 \%)$ \\
\hline Banking/finance & $6(5 \%)$ & \\
\hline Total & $129(100 \%)$ & \\
\hline
\end{tabular}

Source: Compiled from Brady's (1996/97)

and Seshego. No data were available for Mankweng. The main employment sector is tertiary / quaternary in nature, with $44 \%$ and $36 \%$ of the businesses in Lebowakgomo and Seshego respectively being retail shops. However, these are not specialised shops (eg chain stores), but are predominantly spaza shops and cash stores.

The absence of quaternary services in the towns is notable. Of the businesses listed in Lebowakgomo and Seshego, $14 \%$ and $17 \%$ are respectively classified as businesses rendering social or community services, and $5 \%$ and $1 \%$ render financial services. The primary and secondary sectors in Seshego make up a larger percentage than in Lebowakgomo, illustrating the absence of industrial development in Lebowakgomo.

On the other hand Pietersburg has made considerable progress in terms of urban growth (eg GDP contribution, population size, economic activity, approved building plans). This city was expected to have an annual growth rate of $7 \%$ until 2000 (Urban-Econ \& De Villiers, 1994). Its economic, political, financial and social institutions (Donaldson, 1999) may be summarised as follows:

- Pietersburg is the biggest industrial complex in the Northern Province and primarily aims to service the consumer market (distribution, packaging, service industries).

- Pietersburg offers numerous community and other services (hospitals, educational institutions, sport and recreational facilities).

- The government sectors are increasingly centralised. Government centres in the former homelands of Lebowakgomo, Giyani and Thohoyandou still perform certain government functions.

- The commercial and accommodation sectors in Pietersburg provide a subregional service to Botswana and Zimbabwe.

- All major South African financial and insurance institutions are represented in the financial sector, and some are expected to open provincial head offices.

- Transport services are available (bus, air, rail, road).

\section{HOUSEHOLD RESOURCES MANAGEMENT SYSTEM}

The family or household is considered part of an ecosystem from a household resources management perspective. It is a subsystem that is constantly interacting with its various environments in its endeavours to satisfy the basic human needs of members of the family.

Closest to the family is its microenvironment, which is in turn surrounded by the macroenvironment. The microenvironment represents the immediate setting for the family system and comprises the physical and social surroundings of the household. The household members have regular personal contact and interaction in this microenvironment. Physical aspects of the microenvironment include the housing, goods or other evidences of spatial territory identified with particular individuals or families, and the social aspects comprise people with whom the family interacts on a personal or support level (Deacon \& Firebaugh, 1988:2931; Engberg, 1990:24-28).

The household's macroenvironment is composed of societal, natural and structured systems beyond the microenvironment. The societal systems with which the household interacts are the sociocultural, political, economic and technological mechanisms and processes by way of which the members fulfil their social roles. The natural and structured systems are the physical and biological settings in which related societal systems function (Deacon \& Firebaugh, 1988:3238; Engberg, 1990:24-28). 
The linkages between the family (household) and the political and economic subsystems may be described as follows:

\section{Political system / family interaction}

The political system influences the family system through laws, regulations, protection and other services. Goods and services (eg education, parks, recreational facilities and libraries) are resources provided by the political system for the family to meet its needs. In return for these services, the family is expected to pay taxes, to vote, to comply with laws and regulations, and to fulfil other civil obligations (Deacon \& Firebaugh, 1988:34-35). This analysis considered some of the household's interaction with its political subsystem. Interactions with societal structures or functions that are provided by the use of government resources (taxes paid by society) were deemed to be relevant, e.g. schools and sport facilities.

\section{Economic system / family interaction}

The economy is expected to provide the quantity and quality of goods and services families need at acceptable prices. The economy is also expected to provide opportunities for family members to participate in its productive processes by way of labour provision and investments, and households expect to receive a reasonable return on their labour and investments. In turn the economy expects families to support it by buying the available goods and services and by providing labour and productive resources (eg investment capital through savings and investments) (Deacon \& Firebaugh, 1988:35). This analysis considered any exchange of money for goods and services or to earn a living as interaction of the household with the economic subsystem.

The natural and structured macroenvironments are the physical and biological surroundings of households within which related societal systems function. These include the man build physical environment $e$. g. towns, roads, communication networks, the natural physical setting (geography) and the accompanying biological systems such as the fauna and flora (Deacon \& Firebaugh, 1988:36; Engberg, 1990:2428)).

Households in the structured environments of Lebowakgomo, Seshego and Mankweng have to interact with their environments to meet their needs. The question is: How do they do this? Do they mainly interact with the societal subsystems in the towns where they live, or do they interact with the societal subsystems in some of the other towns and with those in Pietersburg? One way of answering this question was to investigate the linkages between households and their towns and to determine the nature of those linkages.

Recent work by Cedras (1996) provides an overview of the literature on potential linkages between settlements. The literature covers physical linkages be- cause communities depend heavily on a transport network; economic linkages; movement due to temporary and permanent migration of workers between urbanurban and rural-urban areas; technological linkages which include communication networks - which in turn enhances linkages between people; social interaction; service provision indicating the extent of interdependence between settlements; political and administrative linkages.

This survey covered aspects of economics linkages, social interaction and service provision. These aspects had to be interpreted in terms of an ecological frame of reference for household resources management as described by Deacon and Firebaugh (1988) and Engberg (1990).

Interaction of the household with the political subsystem includes the provision of education and recreational facilities and the household's utilisation of these services and facilities to meet its needs. Studying educational and recreational linkages would therefore provide part of the answer to the question how households in Lebowakgomo, Seshego and Mankweng interact with aspects of the political subsystem in their macroenvironment.

Interaction between households and the economic subsystem includes the provision of labour in exchange for salaries and wages, the use of money to buy goods and services, and the utilisation of financial institutions for investment purposes. Studying economic linkages in terms of place of employment, shopping and services would therefore partly answer the question on the nature of the interaction between households in the three towns and their economic macroenvironment.

The microenvironment is the most intimate environment of the household. The physical microenvironment includes the housing, goods or other evidences of spatial territory that is identified with particular individuals or households. A sense of identity and of attachment to their homes could indicate how satisfied households in the three towns are with their physical microenvironments.

This article describes some linkages between the households from Lebowakgoma, Seshego and Mankweng, with these towns and Pietersburg, and indicate (where possible) some of the implications of these linkages in terms of household resources management.

\section{METHODOLOGY}

This survey was conducted in 1997. An interview schedule was used to interview the 120 households who had been selected to participate in the study.

\section{Development of interview schedule}

The interview schedule consisted of sections for bio- 
graphical information, information about residential status, economic and political linkages. The sections asked for the following information:

- Biographical information: gender and age of household members, number of residents, highest educational qualification of respondent, combined household income, languages spoken at home, main mode of transport

- Residential information:

when did the household settle in the town, where would they prefer to stay, home ownership status and type of house

- Economic linkages: where household member (s) work, where they purchase their groceries, clothing, electrical appliances, car parts, meat, alcohol, building material, where they go for banking, postal, medical and legal services

- Political linkages: where do they usually participate in sports, where do the children go to school (This information was categorised under political linkages because schools and sport facilities are provided by the government nationally, provincially and locally.)

The interview schedule consisted of open-ended and closed questions. The closed questions appeared exclusively in the linkage sections of the interview schedule.

The interview schedule was tested in a pilot study by interviewing five households in Mankweng. No changes were required.

\section{Selection of respondents}

The only reliable source for identifying a sample was the street plan of each town. From these plans the number of stands per zone (suburb) were determined. A systematic sample was drawn of 40 households per town. Table 2 shows the number of interviews conducted per town and its respective zones. Zones without residential dwellings appear as empty cells in Table 2.

\section{Survey and analysis of data}

The survey was conducted in Lebowakgomo, Mankweng and Seshego. Trained honours students from the University of the North interviewed the identified head of the household. When the identified head of the household was not present, an appropriate substitute was identified.

The interviews were conducted during the weekends (Saturday afternoon and evening, and Sunday afternoon) because most household members were at home then. The interviews were conducted in mid month because the families usually went to Pietersburg for shopping and services when they were paid at the end of the month. Data were coded, percentages calculated, and some cross-tabulations were made.

\section{RESULTS AND DISCUSSION}

\section{Description of respondents}

The sociodemographic profile of the respondents is presented in Table 3.

Quite similar results were obtained for the households in the three towns, except in terms of education. The combined incomes of most households were in the R2 001 to R4 000 income bracket, reflecting a lowmiddle-income status. The majority of households spoke North Sotho, and uses either combi-taxis or their own cars for transport. The educational level of the respondents in Mankweng was notably higher than that of the respondents in Seshego and Lebowakgomo. This could be because Mankweng developed as an educational centre with the University of the North within its boundaries.

\section{Physical and social microenvironments}

Table 4 contains information that reflects aspects of the microenvironment of the households.

More than $80 \%$ of the respondents owned their properties, and these were predominantly formal, serviced dwellings. More than $60 \%$ of the respondents had

TABLE 2: SAMPLE DRAWN FOR URBAN LINKAGES SURVEY IN LEBOWAKGOMO, SESHEGO AND MANKWENG $(\mathbf{N}=\mathbf{1 2 0})$

\begin{tabular}{|l|c|c|c|c|c|c|c|c|c|}
\hline \multicolumn{1}{|c|}{ Town } & Zone 1 & Zone 2 & Zone 3 & Zone 4 & Zone 5 & Zone 8 & $\begin{array}{c}\text { Total in } \\
\text { sample }\end{array}$ & $\begin{array}{c}\text { Universe* }^{\star} \\
\begin{array}{c}\text { Sample } \\
\text { covered (\%) }\end{array}\end{array}$ \\
\hline Seshego & 5 & 6 & 6 & 9 & 7 & 7 & 40 & 10328 & 0,39 \\
\hline Mankweng & 10 & 6 & 9 & 15 & - & - & 40 & 2600 & 1,54 \\
\hline Lebowakgomo & 14 & 11 & - & - & 15 & - & 40 & 2980 & 1,34 \\
\hline Total & & & & & & & 120 & & \\
\hline
\end{tabular}

Note: Approximate figures. Residential stands were determined from available, outdated town maps. Undeveloped stands could therefore not be identified. 
TABLE 3: $\quad$ SOCIODEMOGRAPHIC PROFILE OF RESPONDENTS $(\mathrm{N}=120)$

\begin{tabular}{|c|c|c|c|}
\hline Variable & $\begin{array}{c}\text { Seshego } \\
(\%)\end{array}$ & $\begin{array}{c}\text { Mankweng } \\
(\%)\end{array}$ & $\begin{array}{c}\text { Lebowakgomo } \\
(\%)\end{array}$ \\
\hline Average number of members per household & 5,5 & 4,8 & 5,3 \\
\hline \multicolumn{4}{|l|}{ Highest educational qualification of respondent } \\
\hline Primary school & 2,5 & 7,5 & 5,0 \\
\hline Grades 8-12 & 27,5 & 10,0 & 25,0 \\
\hline Matriculation certificate & 30,0 & 17,5 & 22,5 \\
\hline Diploma & 20,0 & 25,0 & 25,0 \\
\hline Degree & 20,0 & 40,0 & 22,5 \\
\hline \multicolumn{4}{|l|}{ Combined household income per month (R) } \\
\hline $\begin{array}{lll}1 & - & 1000 \\
\end{array}$ & 7,5 & 10,0 & 15,0 \\
\hline $1001-2000$ & 12,5 & 7,5 & 12,5 \\
\hline $2001-4000$ & 27,5 & 37,5 & 22,5 \\
\hline $4001-6000$ & 15,0 & 15,0 & 20,0 \\
\hline $6001-8000$ & 15,0 & 15,0 & 17,5 \\
\hline $8001-10000$ & 2,5 & 5,0 & 2,5 \\
\hline$>10000$ & 0.0 & 7.5 & 2,5 \\
\hline Refused to answer & 20,0 & 2,5 & 7,5 \\
\hline \multicolumn{4}{|c|}{ Languages spoken at home (more than one option possible) } \\
\hline English & 0,0 & 2,5 & 2,5 \\
\hline North Sotho & 97,5 & 95,0 & 90,0 \\
\hline Tsonga/Shangaan & 0,0 & 2,5 & 2,5 \\
\hline Tswana & 0,0 & 0,0 & 2,5 \\
\hline Other & 2,5 & 0,0 & 2,5 \\
\hline \multicolumn{4}{|l|}{ Household's main mode of transport } \\
\hline Combi-taxi & 52,5 & 47,5 & 40,0 \\
\hline Own car & 32,5 & 47,5 & 40,0 \\
\hline Bus & 10,0 & 2,5 & 15,0 \\
\hline Other & 5,0 & 2,5 & 5,0 \\
\hline
\end{tabular}

settled in the three towns after 1981. A strong sense of identity and attachment developed.

Table 5 contains a summary of the places where the respondents would prefer to live. The majority chose their own towns $(63 \%$ of Seshego's, $65 \%$ of Mankweng's and $58 \%$ of Lebowakgomo's respondents preferred their own towns above others). On average most preferred to live in Mankweng (26\%), followed by Seshego (25\%) and Lebowakgomo (20\%). Piet- ersburg was the fourth choice (19\%) as very few households wanted to live there. A few respondents explained why:

- Rent in Lebowakgomo is cheaper than in Pietersburg

- The standard of living is a bit better in Pietersburg but I won't be able to afford the expense

- There is a close link with neighbours and we don't live in isolation

TABLE 4:

RESIDENTIAL INFORMATION (N = 120)

\begin{tabular}{|l|c|c|c|}
\hline \multicolumn{1}{|c|}{ VARIABLE } & \multicolumn{1}{|c|}{$\begin{array}{c}\text { SESHEGO } \\
(\%)\end{array}$} & $\begin{array}{c}\text { MANKWENG } \\
(\%)\end{array}$ & $\begin{array}{c}\text { LEBOWAKGOMO } \\
\text { (\%) }\end{array}$ \\
\hline Home ownership & 95,0 & 82,5 & 87,5 \\
\hline House type & & & 100,0 \\
\hline Formal, serviced house & 95,0 & 77,5 & 0,0 \\
\hline Informal, limited services & 5,0 & 17,5 & 0,0 \\
\hline Other & 0,0 & 5,0 & 2,5 \\
\hline Time of location & & & 12,5 \\
\hline $1960-1970$ & 17,5 & 0,0 & 55,0 \\
\hline $1971-1980$ & 15,0 & 5,0 & 22,5 \\
\hline $1981-1990$ & 40,0 & 40,0 & 7,5 \\
\hline $1991-1994$ & 22,5 & 37,5 & \\
\hline After 1995 & 5,0 & 17,5 & \\
\hline
\end{tabular}


TABLE 5: CROSS-TABULATION OF CURRENT PLACE OF RESIDENCE AND WHERE RESPONDENTS WOULD PREFER TO LIVE (\% OF $\mathrm{N}=120)$

\begin{tabular}{|l|c|c|c|c|c|c|}
\hline & \multicolumn{5}{|c|}{ Preferred place to live } & \\
\cline { 2 - 7 } & Pietersburg & Seshego & Mankweng & Lebowakgomo & Other & Total \\
\hline $\begin{array}{l}\text { Preference for place of resi- } \\
\text { dence indicated by all respon- } \\
\text { dents }\end{array}$ & 19,2 & 25,0 & 25,8 & 20,0 & 10,0 & 100,0 \\
\hline Current place of residence & & & & & & \\
\hline Seshego & 20,0 & 62,5 & 5,0 & 0,0 & 12,5 & 100 \\
\hline Mankweng & 22,5 & 2,5 & 65,0 & 2,5 & 7,5 & 100 \\
\hline Lebowakgomo & 15,0 & 10,0 & 7,5 & 57,5 & 10,0 & 100 \\
\hline
\end{tabular}

- I am used to the place and it will be difficult to adjust to a new place

- This location is still in a better condition compared to other black locations

- I won't leave for Pietersburg because I want to enjoy African beliefs, including tradition and culture

These statements are indicative of interaction between the households in their social microenvironment and the importance of such microenvironmental interaction.

\section{Household interaction with the economic macro- environment}

The interaction between households and aspects of their economic macroenvironment is discussed in terms of their places of employment, where they do their shopping and where they use other services.

Employment As indicated above, one way of interacting with the economic macroenvironment is to provide labour in exchange for salaries or wages. The available information on economic activities in Lebowakgomo and Seshego (Table 1) could lead one to assume that most households in Lebowakgomo, Seshego and Mankweng use Pietersburg to secure money as a household resource. However, the findings of this survey show this assumption to be untrue (see Table 6). The respondents in the 120 households had to indicate where the head of the household and the spouse (the two chief breadwinners) worked. There were 168 breadwinners in the sample of 120 households, in other words $70 \%$ of a possible 240 breadwinners were employed. According to Table 6 , the largest single place of employment was the surrounding rural area $(23 \%)$, followed by Pietersburg (20\%), Mankweng (19\%), Lebowakgomo (17\%), and Seshego (10\%). Of the respondents employed in Pietersburg, 32\% came from Seshego, 15\% from Lebowakgomo and 14\% from Mankweng. Most of the respondents in Seshego were employed in Pietersburg (32\%), Seshego (30\%) and the surrounding rural area $(18 \%)$, whereas $50 \%$ of the respondents in Mankweng were employed in Mankweng. The majority of respondents in Lebowakgomo were employed in Lebowakgomo $(40 \%)$ and in the surrounding rural area (35\%).
The distance these residents have to travel to places of employment in Pietersburg could explain the above findings. Lebowakgomo is $55 \mathrm{~km}$ from Pietersburg, Mankweng $30 \mathrm{~km}$, and Seshego $13 \mathrm{~km}$. The money for transport, part of the household's available resources, could be why household members would rather work near their own towns. This would release money to meet the needs of individual household members.

Shopping and services Consumer and investment interaction also take place in the economic macroenvironment. Households have to buy groceries, clothes, meat, electrical appliances and services (medical, legal, postal) to satisfy family needs. The household also interacts with the economic macroenvironment when its members make use of financial services (banking to manage financial resources and to make investments).

Shopping facilities in the three towns are restricted to a limited number of shopping centres, spaza shops and street cafés. None of the well-known supermarket chain stores or other national retail outlets are available. There is also little variety in banking, insurance and legal services in the three towns. The only noteworthy services are postal and medical services. It is therefore to be expected that most of the respondents did their shopping and other personal business in the regional service centre of Pietersburg (see Table 7). Household goods such as groceries (92\%), clothing (95\%), and meat (73\%) are mainly purchased in the city. Not much can be deduced from lowpercentage shopping patterns such as the purchasing of alcohol and car parts because many respondents say they do not consume the first and less than $50 \%$ of the respondents own their own vehicles. Regarding services it can be seen that medical and postal services are sufficient in the three towns whereas banking (91\%), insurance (81\%) and legal (65\%) services are mainly provided in Pietersburg.

Using banking, insurance and legal services and purchasing regularly used household necessities such as groceries, clothing and meat in Pietersburg have implications for the household's money. It is clear from a comparison of the percentages of respondents who work and shop in Pietersburg that many travel to Piet- 
TABLE 6: $\quad$ PLACE OF RESIDENCE BY TOWN WHERE EMPLOYED $(\mathrm{N}=168)$

\begin{tabular}{|l|c|c|c|c|c|c|c|}
\hline & \multicolumn{9}{|c}{ Town where employed } & \multicolumn{1}{c}{} \\
\cline { 2 - 8 } & Pietersburg & Seshego & Mankweng & Lebowakgomo & Rural & Other & Total \\
\hline $\begin{array}{l}\text { Percentage of respon- } \\
\text { dents employed per } \\
\text { city / town }\end{array}$ & 20,2 & 10,1 & 18,5 & 16,7 & 23,2 & 11,3 & 100,0 \\
\hline Place of residence & & & & & & & \\
\hline Seshego & 31,6 & 29,8 & 5,3 & 8,8 & 17,5 & 7,0 & 100 \\
\hline Mankweng & 14,3 & 0,0 & 50,0 & 1,8 & 17,0 & 16,1 & $100^{*}$ \\
\hline Lebowakgomo & 14,5 & 0,0 & 0,0 & 40,0 & 34,5 & 10,9 & 100 \\
\hline
\end{tabular}

TABLE 8: $\quad$ WHERE RESPONDENTS' CHILDREN ATTEND SCHOOL $(\mathrm{N}=62)$

\begin{tabular}{|l|c|c|c|c|}
\hline \multirow{2}{*}{} & \multicolumn{3}{|c|}{ Town where children attend school (\%) } \\
\cline { 2 - 5 } & Pietersburg & Seshego & Mankweng & Lebowakgomo \\
\hline $\begin{array}{l}\text { Percentage of respondents' } \\
\text { children attending school in } \\
\text { city / town }\end{array}$ & 22,7 & 22,6 & 29,6 & 25,0 \\
\hline Place of residence & 32,1 & 67,9 & 0,0 & 0,0 \\
\hline Seshego & 11,1 & 0,0 & 88,8 & 0,0 \\
\hline Mankweng & 25,0 & 0,0 & 0,0 & 75,0 \\
\hline Lebowakgomo & & & & \\
\hline
\end{tabular}

ersburg with the express goal of doing their shopping in the city, at the big chain stores. The variety of goods offered in these shops is generally much greater than in the smaller shops in the towns, and the prices are lower due to economy of scale.

Household members who do the shopping have to travel the required distance to Pietersburg, thus using some of the available money for travelling expenses instead of purchasing necessary goods. This could cause diminished satisfaction of household needs. Households have to consider the opportunity cost involved in buying in Pietersburg versus buying in their hometowns.

\section{Household interaction with the political macroen- vironment}

In this study interaction with the political subsystem as part of the macroenvironment was delineated as interaction with two types of services/facilities provided by the political subsystem for use by all households in a community or society. These are the educational services provided by the national or provincial government, and sporting facilities provided by the local government in return for payment of taxes.

Education and recreation

Of the respondents (see Table 8) who have children at school, 23\% go to school in Pietersburg, $23 \%$ in Seshego, 30\% in
Mankweng, and 25\% in Lebowakgomo. Pietersburg is the only educational centre that draws learners from neighbouring towns. The lowest percentage comes from Mankweng, an educational centre with the University of the North within its boundaries. The other learners attend school in their own areas, namely Mankweng (89\%), Seshego (68\%), and Lebowakgomo $(75 \%)$. It may be assumed that most children who attend school in Pietersburg travel with their parents who work in the city.

This aspect may have implications for household resources management in terms of time management by parents and children. They have to leave home in time for school and work, and make time available for the children to do their schoolwork. It may also be more expensive to attend schools in Pietersburg (school fees and after-school care). If the children do not travel with their parents, additional money would be required for transport. Opportunity costs have to be considered because the children may gain more from attending school in Pietersburg (facilities and educational opportunities).

A large percentage of the respondents did not participate in outdoor recreation (48\%). The Mankweng and Seshego respondents who participated in Pietersburg came to $35 \%$ and $30 \%$ respectively. Lebowakgomo residents preferred their own town (18\%) and the adjoining rural areas (50\%). The exact nature of these 


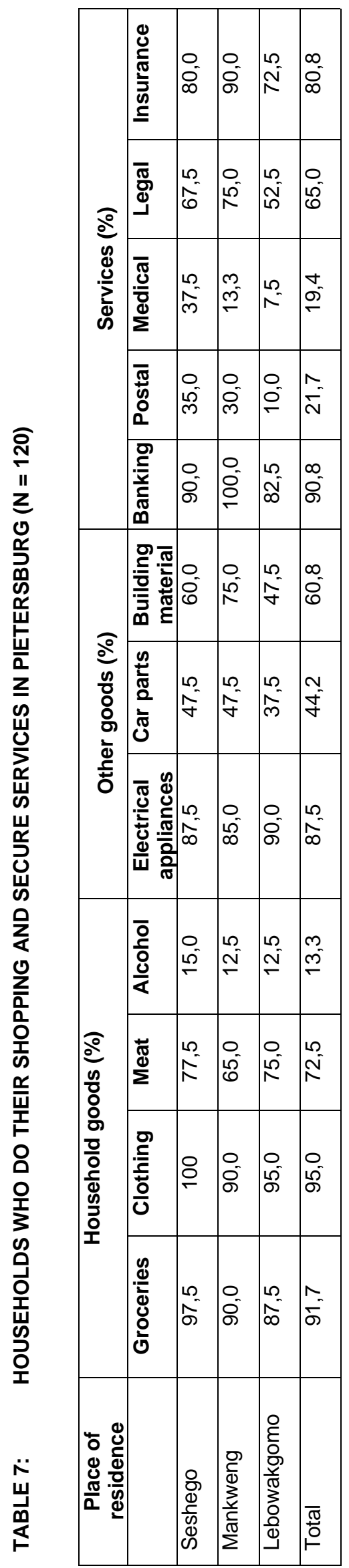

activities was not determined. All three towns have soccer stadiums where soccer matches regularly take place. However, $38 \%$ of the respondents never attended soccer/other outdoor sports as spectators, and those who did usually did so in Pietersburg (39\%).

\section{CONCLUSION}

This study attempted to investigate and describe the linkages households formed with former Lebowa homeland towns and Pietersburg. Urban study surveys often ignore the household resources management perspective. This finding is also true of this survey which was conducted by an urban geographer whose findings were only afterwards contextualised within a resources management framework. An integrated approach would be of considerable value in similar future studies.

Certain shortcomings in this linkage survey should be highlighted, for example travelling time to and from towns, the relative prices of goods and services, travel expenses, and family arrangements around schoolgoing children. One could also argue that households in a dispersed urban macroenvironment might be negatively affected by the expense of travelling to Pietersburg for technological interaction and the consequent additional financial burden.

The most striking observations pertain to the social system and linkages with Pietersburg in terms of place of employment, educational and recreational interaction. The low average percentages indicate that households organise their economic, sociocultural and social interaction within their own spatial environments so that a strong sense of identity and communalism prevails.

\section{REFERENCES}

CEDRAS, LA. 1996. Die implikasie van landelike-stedelike interaksie vir plaaslike owerheidsbestuur in die Stellenboschdistrik. MA-verhandeling, Universiteit van Stellenbosch.

DEACON, RE \& FIREBAUGH, MF. 1988. Family resource management. Principles and applications. London: Allyn \& Bacon.

DONALDSON, SE. 1999. Restructuring in a South African city during transition: urban development and transformation in Pietersburg during the 1990s. Unpublished DPhil dissertation, University of Stellenbosch.

ENGBERG, E. 1990. Rural households and resource allocation for development. An ecosystem perspective. Rome: Food and Agriculture Organization of the United Nations. NORTHERN PROVINCE BUYERS' GUIDE 1996/1997. Johannesburg: Brady's.

URBAN-ECON \& DE VILLIERS, F \& ASSOCIATES. 1994. Strategy for rural settlement development prioritisation in Lebowa. Lebowakgomo: Report for Department of Home Affairs, Lebowa Government.

WIDDIS, RW. 1991. Belleville and environs: continuity, change and the integration of town and country during the $19^{\text {th }}$ century. Urban History Review 19(3):181-208. 